\title{
Amiloidosis oral nodular
}

\section{Oral nodular amyloidosis}

\section{P. Martos Díaz', J. Sastre Pérez², M. Mancha de la Plata', T. Reina³ , S. Rosón Gómez', L. Naval Gías²}

Resumen: Introducción. La amiloidosis constituye una entidad marcada por el depósito de amiloide en diferentes tejidos. En la cavidad oral se manifiesta habitualmente en forma de macroglosia, y más raramente, como nódulos dispuestos en la superficie. Caso clínico. Varón afecto de Mieloma Múltiple, que comienza con lesiones nodulares en labio inferior y lengua. A raíz de estas lesiones, mediante estudio histológico, es diagnosticado de Amiloidosis Sistémica. Discusión. Los nódulos amiloideos en la cavidad oral, constituyen una manifestación rara de la amiloidosis sistémica. Su aparición conlleva la necesidad de realizar un diagnostico diferencial con otras entidades y el diagnostico de certeza se obtiene mediante el análisis histológico.

Palabras clave: Amiloidosis lingual; Rojo congo; Nódulos amiloideos; Mieloma múltiple; Proteína amiloidea.

Recibido: 20.03 .07

Aceptado: 31.10 .07
Abstract: Introduction. Amyloidosis is a condition characterized by the deposit of amyloid in different tissues. In the oral cavity it is usually manifested as macroglossia and, more rarely, as nodules on the surface. Clinical case. A man had multiple myeloma that began with nodular lesions of the lower lip and tongue. As a result of these lesions, the patient was diagnosed of systemic amyloidosis by histological study. Discussion. Amyloid nodules in the oral cavity are a rare manifestation of systemic amyloidosis. Its appearance entails the necessity to make I diagnose differential with other organizations and I diagnose of certainty is obtained by means of the histological analysis.

Key words: Lingual amyloidosis; Congo red; Amyloid nodules; Multiple myeloma; Amyloid protein.

1 Médico Residente de Cirugía Oral y Maxilofacial.

2 Médico Adjunto. Servicio de Cirugía Oral y Maxilofacial.

3 Médico Residente. Servicio de Anatomía Patológica.

Hospital Universitario de la Princesa. Madrid, España

\section{Correspondencia:}

Pedro Martos Díaz

Hospital de la princesa. Servicio de Cirugía Oral y Maxilofacial.

c/ Diego de León 62

28006 Madrid, España

Email: plmartos9@hotmail.com 


\section{Introducción}

La amiloidosis es una enfermedad de etiología desconocida, y es parte de un conjunto de entidades que se caracterizan por el depósito de proteinas de estructura fibrilar en el espacio extracelular de diferentes tejidos. ${ }^{1,2}$ La incidencia de la amiloidosis en la población es de 8 personas por millón de habitantes al año, ${ }^{3}$ dando lugar a diferentes alteraciones en función de la cuantía del depósito y del órgano afecto.

La proteína amiloide destaca por la capacidad para identificarse al microscopio óptico mediante la tinción con rojo congo, observando bajo luz polarizada, una birrefringencia verde manzana. Esto se ha relacionado con su configuración , $\beta$-plegada.4,5

La clasificación de la amiloidosis ha sido difícil y controvertida durante mucho tiempo. ${ }^{6}$ Actualmente se basa en la naturaleza química de la proteína precursora. En dicha clasificación, los tres tipos principales de amiloidosis son 1) La amiloidosis primaria o $A L, 2$ ) La amiloidosis familiar por mutación de la transtiretina o ATTR, 3) La amiloidosis secundaria o AA, que se asocia a enfermedades crónicas o a Fiebre Mediterránea Familiar, en cuyo caso presentaría una herencia autosómica recesiva. ${ }^{7}$

En el curso de esta enfermedad pueden verse envueltos múltiples tejidos y órganos tales como: aparato gastrointestinal, riñón, corazón, aparato musculoesquelético, piel, tejido nervioso. La principal causa de muerte son las arritmias cardiacas y la insuficiencia renal. ${ }^{1,2}$

La afectación de la cavidad oral sucede hasta el $40 \%$ de los casos. Esta es la localización que más frecuente se ha visto afectada, distinguiéndose dos entidades: ${ }^{8,9}$

1. Macroglosia, la cual se manifiesta por un aumento difuso del tamaño de la lengua y pérdida de su elasticidad.

2. Acúmulos de material amiloide formando lesiones nodulares que se pueden distribuir a nivel de la lengua, glándulas salivares y labios. ${ }^{10}$ Dichas manifestaciones se producen con mucha menor frecuencia que las anteriores. ${ }^{11}$

En el presente artículo describimos un cuadro de amiloidosis oral primaria asociada a mieloma múltiple, que cursó con la aparición de lesiones nodulares a nivel lingual y labial. Aportamos datos sobre la clínica, histología e imágenes, a la vez que se hace una revisión de la literatura.

\section{Caso clínico}

Paciente varón de 57 años de edad con antecedentes personales de Hipertensión arterial y Hepatitis C. Diagnosticado de plasmocitoma óseo solitario en undécima costilla, que evolucionó a Mieloma Múltiple tipo Bence Jones Lambda. En tratamiento con diálisis peritoneal desde hacía 5 años por insuficiencia renal crónica secundaria a nefropatía asociada a Mieloma Múltiple.

Consulta por varias lesiones en lengua y labio inferior izquierdo, de 2 meses de evolución que le producían importante escozor. En la exploración se observan cinco lesiones nodulares a nivel de punta de la lengua, cara lateral de esta y labio izquierdo. Tres de los nódulos, presentaban un color violáceo con el centro lige-

\section{Introduction}

Amyloidosis is a disease of unknown etiology and is one of a group of conditions characterized by the deposit of proteins of fibrillary structure in the extracellular space of different tissues. ${ }^{1,2}$ The incidence of amyloidosis in the population is 8 people per million inhabitants a year, ${ }^{3}$ giving rise to different disorders depending on the amount deposited and the organ affected.

Amyloid protein is noteworthy due to the capacity to be identified under optical microscope by means of red Congo stain, observing apple-green birefringence under polarized light. This has been related with its , $\beta$-folded configuration. 4,5

The classification of amyloidosis has been difficult and debated for a long time. ${ }^{6}$ At present it is based on the chemical nature of the precursor protein. In this classification, the three main types of amyloidosis are 1) primary amyloidosis or $A L, 2)$ familial amyloidosis due to transthyretin mutation or ATTR, and 3) secondary amyloidosis, or AA, that is associated with chronic disease or familial Mediterranean fever, in which case the patient would present recessive autosomal heredity. ${ }^{7}$

In the course of this disease, multiple tissues and organs can be involved, such as: gastrointestinal system, kidney, heart, musculoskeletal system, skin, nervous tissue. The primary cause of death is cardiac arrhythmia and renal insufficiency. ${ }^{1,2}$

The oral cavity is involved in up to $40 \%$ of cases. This is the most common location affected, two conditions being differentiated: 8,9

1. Macroglossia, which is manifested as a diffuse increase in the size of the tongue and loss of elasticity.

2. Clumps of amyloid material forming nodular lesions that may be distributed in the tongue, salivary glands, and lips. ${ }^{10}$ This variant occurs less frequently than the above symptoms. ${ }^{11}$

In the present article we report a case of primary oral amyloidosis associated with multiple myeloma that coursed with nodular lesions of the tongue and lips. We offer data on the clinical manifestations, histology, and imaging and review the literature.

\section{Clinical case}

A 57 year-old man with a history of arterial hypertension and hepatitis $C$ was diagnosed as solitary bone plasmocytoma of the eleventh rib that evolved to multiple myeloma, Bence Jones Lambda type. The patient had been treated peritoneal dialysis for 5 years for chronic renal insufficiency secondary to nephropathy associated with multiple myeloma.

The patient consulted for several lesions of the tongue and left lower lip that had been present for 2 months and produced irritation. The examination disclosed five nodular 
ramente blanquecino y los otros dos, más claros, sin tonalidad violácea (Figs. 1 y 2). La consistencia a la palpación era algo indurada. El nódulo de la cara lateral de la lengua presentaba un diámetro mayor de 1,5 cm, en el labio, el mayor de ellos, tenía $1,2 \mathrm{~cm}$ y el tamaño del resto de los nódulos era inferior a estas medidas. Al mes de la exploración oral, el paciente acude de nuevo, presentando lesiones de color púrpura perioculares bilaterales (Fig. 3).

Se procede a realizar un total de 3 biopsias, una del labio y dos de las lesiones linguales. Dichas biopsias se describien como depósitos densos de material hialino, acelular, homogéneo que ocupa toda la submucosa separando haces musculares y con afectación de paredes vasculares. Estos depósitos se tiñen con la tinción de Rojo Congo (Fig. 4) presentado una birrefringencia verde manzana. Además con la tinción de tioflavina T (Fig. 5) se observa una fluorescencia verde-amarillenta. En el resto de la mucosa se observa una ligera acantosis con paraqueratosis y un leve infiltrado linfoplasmocitario.

Ante los hallazgos observados, se solicita la realización de una Puncion aspiración con aguja fina (PAAF) de grasa abdominal, que resulto positiva para material amiloide con tinción de Rojo Congo. Se confirma con esto el diagnostico de Amiloidosis Sistémica, y se realizan diferentes pruebas que objetivan una alteración multiorgánica, con afectación de piel, tejido nervioso, aparato gastrointestinal, corazón y riñón.

A los 15 meses del diagnostico de la Amiloidosis, fallece el paciente como consecuencia de un megacolon y por fallo multiorgánico.

\section{Discusión}

La amiloidosis consiste en una enfermedad sistémica de etiología desconocida, que agrupa un conjunto de entidades cuya característica principal es el depósito de un material denominado amiloide. ${ }^{1,2}$ El material amiloide está constituido por proteínas de estructura fibrilar anormal, que se forma por inmunoglobulinas degeneradas, o derivados de un reactante de fase aguda del suero conocido como amiloide $\mathrm{A}$, o de productos derivados de los queratinocitos, como resultado de lesión epidérmica local que se deposita en el espacio extracelular de múltiples tejidos.

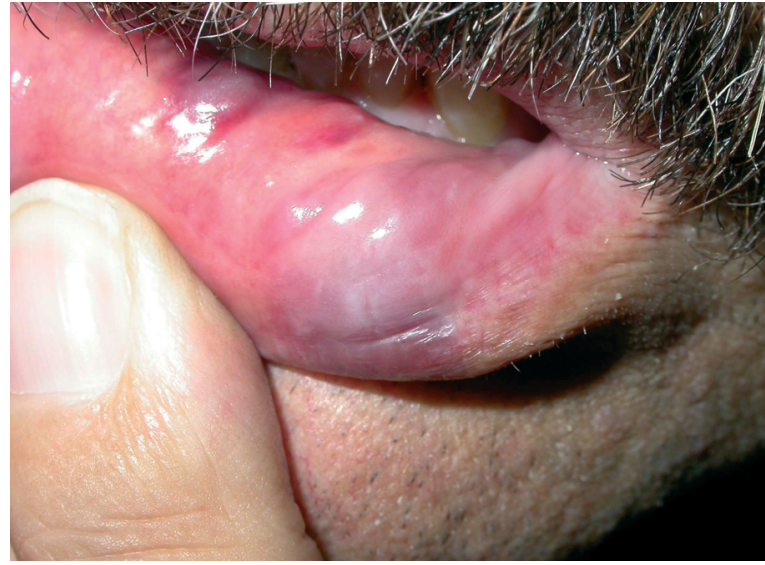

Figura 1. Lesión nodular amiloidea en labio inferior. Figure 1. Amyloid nodular lesion in the lower lip.

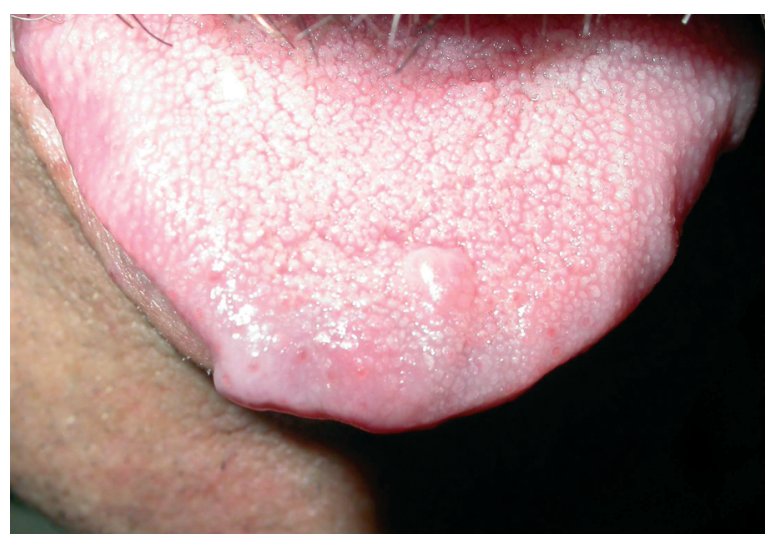

Figura 2. Lesiones nodulares amiloideas en superficie lingual. Figure 2. Amyloid nodular lesions on the lingual surface.

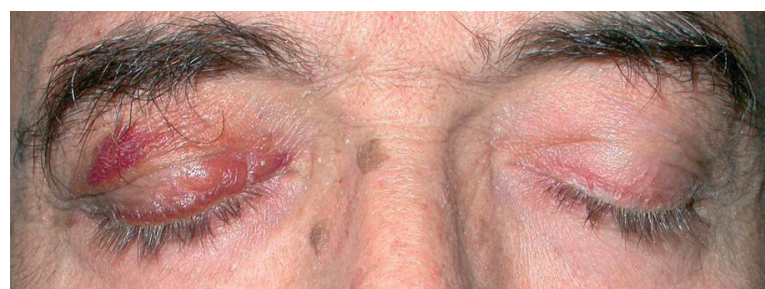

Figura 3. Coloración purpúrica periocular. Figure 3. Periocular purpural coloring. lesions on the tip and side of the tongue and left lip. Three of the nodules were purplish in color with a slightly whitish center and the other two were lighter-colored, without a purplish tone (Figs. 1 and 2). The consistency was somewhat indurated on palpation. The nodule on the side of the tongue had a diameter of more than 1.5 $\mathrm{cm}$. The largest nodule on the lip measured $1.2 \mathrm{~cm}$ and the rest of the nodules were smaller. One month after the oral examination, the patient had bilateral periocular purple-colored lesions (Fig. 3).

A total of 3 biopsies were made, one of the lip and two of the tongue lesions. These biopsies are described as dense deposits of hyaline, acellular, homogeneous material that occupies the entire submucosa, separating muscular bundles and affecting vascular walls. These deposits stain with Congo red (Fig. 4), presenting apple-green birefringence. Thioflavine T stain (Fig. 5) elicits a yellowish-green fluorescence. In the rest of the mucosa, mild acanthosis is observed with parakeratosis and a slight lymphoplasmocytic infiltration.

Based on these findings, a fine needle aspiration biopsy (FNAB) was ordered of the abdominal fat, which was positive for amyloid material with Congo red stain. The diagnosis of systemic amyloidosis was confirmed and different tests were made that showed a multiorganic disorder that affected the skin, nerve tissue, gastrointestinal system, heart, and kidney.

Fifteen months after the diagnosis of amyloidosis, the patient died as a result of megacolon and multiorgan failure.

\section{Discussion}

Amyloidosis is a systemic disease of unknown etiology that groups a series of disorder whose primary characteris- 
La clasificación más actualizada de la Amiloidosis, se realiza en función de la proteína precursora. ${ }^{7}$ Entre los diferentes subgrupos, en la Amiloidosis Primaria o $\mathrm{AL}$, la proteína amiloide está compuesta por inmunoglobulinas de cadena ligera, producidas por clones de células plasmáticas, asociándose en un alto porcentaje a Mieloma Múltiple. En este grupo, las fibrillas pueden depositarse a nivel de piel, hígado, riñones, aparato digestivo, etc.

En el caso expuesto, la proteína anómala se origina de las células plasmáticas malignas del mieloma, que dan lugar a la producción de una cantidad excesiva de cadenas ligeras de inmunoglobulinas tipo Lambda. Este tipo de amiloidosis por depósito de cadenas ligeras se ha asociado únicamente a discrasias plasmocelulares $^{1}$

Las manifestaciones clínicas de la amiloidosis a nivel oral, se pueden producir hasta en un $40 \%$ de las formas primarias, pero son raras en las secundarias, y extremadamente raras en las formas localizadas, habiéndose descrito en la literatura algún caso aislado de depósitos de material amiloide a nivel oral sin evidencia de afectación sistémica. ${ }^{12,13}$

Entre las manifestaciones orales, lo más frecuente es un cuadro de aumento difuso de la lengua que denominamos macroglosia. La lengua va perdiendo las cualidades elásticas, haciéndose cada vez más rígida y de mayor tamaño. Esta situación puede evolucionar hasta producir alteraciones a nivel del habla, masticación, deglución, y pudiendo producir en estadíos avanzados una incapacidad para alojar de forma completa el volumen lingual dentro del continente de la cavidad oral, llegándose incluso a impedir la ventilación. ${ }^{14}$ En estos casos avanzados, el tratamiento debe ser quirúrgico, realizando glosectomía parcial con la finalidad de aliviar la sintomatología, así como para disminuir las alteraciones estéticas. ${ }^{15}$

En nuestro caso, no se trataba de una macroglosia, sino que el paciente presentaba la segunda entidad descrita en la cavidad oral característica de esta enfermedad aunque mucho más rara, consistente en lesiones nodulares a nivel lengua y labios. Estas lesiones se describen también en glándulas submandibulares. En una serie publicada por Van der Waal et al en el 2002,11 de 11 casos de amiloidosis de la cavidad oral en un periodo de 31 años

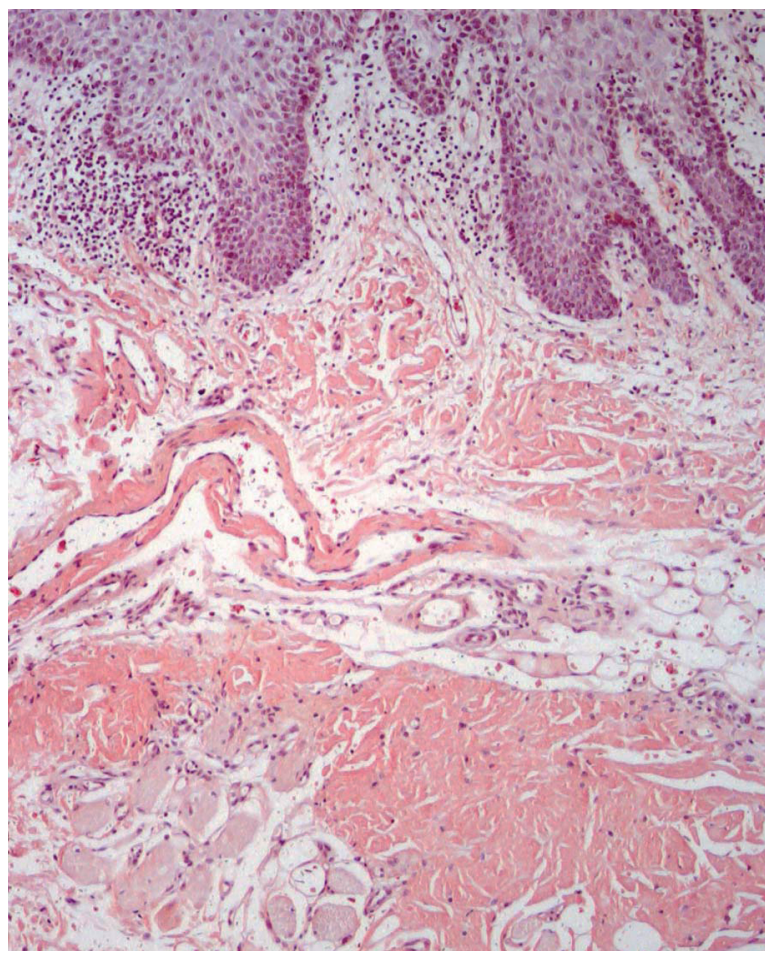

Figura 4. Mucosa lingual. Tinción de Rojo Congo. Material acelular en la submucosa, separando los haces musculares.

Figure 4. Lingual mucosa. Congo red stain. Acellular material in the submucosa, separating muscle bundles.

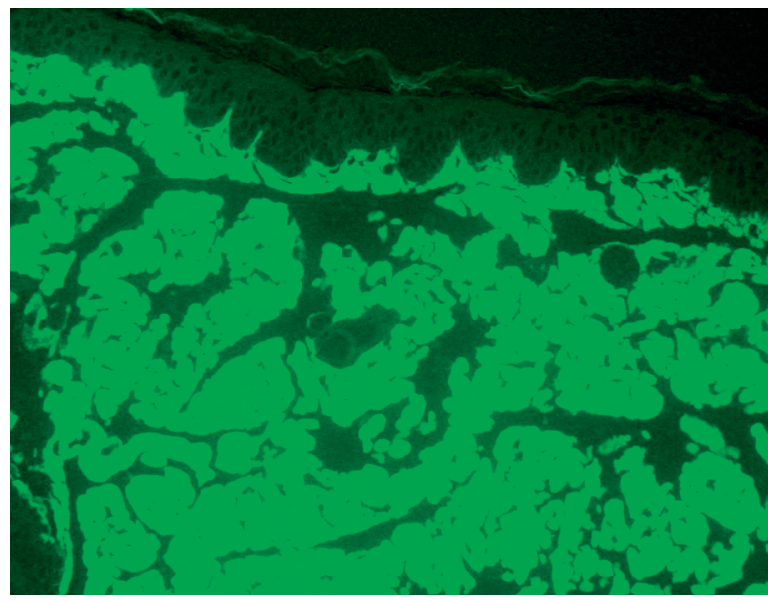

Figura 5. Mucosa lingual. Tinción con Tioflavina T. Los depósitos hialinos presentan una fluorescencia de coloración verdeamarillenta intensa.

Figure 5. Lingual mucosa. Thioflavine T stain. Hyaline deposits present an intense yellowish-green colored fluorescence. tic is the deposit of a material known as amyloid. ${ }^{1,2}$ Amyloid material is constituted by proteins of abnormal fibrillary structure. It is formed by degenerated immunoglobulins or derived from an acute phase serum reactant known as amyloid A, or from products derived from keratinocytes, as a result of a local epidermal lesion that is deposited in the extracellular space of a variety of tissues. The most modern classification of amyloidosis is based on the function of the precursor protein.7 Among the different subgroups, in primary amyloidosis, or AL, the amyloid protein consists of lightchain immunoglobulins produced by clones of plasma cytic cells, with a high percentage associated with multiple myeloma. In this group, fibrils may be deposited in the skin, liver, kidneys, digestive system, and elsewhere.

In the case reported here, the anomalous protein originates from the malignant plasmatic cells of myeloma, which gives rise to the production of an excessive amount of light chains of Lambda type immunoglobulins. This type of amyloidosis due to light chain deposit has been associated only with plasmocellular dyscrasias. ${ }^{1}$

Oral clinical manifestations of amyloidosis can occur in up to $40 \%$ of the primary forms, but are rare in secondary forms and extremely rare in localized forms. Only isolated cases of oral amyloid deposits without evidence of systemic affectation have been described in the literature. ${ }^{12,13}$

Among the oral manifestations, the most frequent a diffuse increase in the tongue that we call macroglossia. The tongue loses its elasticity, becoming increasingly stiff and larger in size. This situation can evolve to produce speech, chewing, and swallowing disorders. In advanced stages, the tongue 
de seguimiento, $\tan$ solo 2 se presentaron en forma de nódulos amiloideos, mientras que los 9 restantes se manifestaron en forma de macroglosia. Estas alteraciones consisten en lesiones nodulares de diversos tamaños, induradas a la palpación y que frecuentemente adoptan una coloración blanco amarillenta. ${ }^{16}$ Se distribuyen sobre todo por la superficie lingual, encontrándose principalmente en el dorso. También se pueden observar a nivel de otras localizaciones de la mucosa oral como en paladar, encías, suelo de boca y labios como es el caso del paciente descrito.

El diagnóstico diferencial de los nódulos por amiloidosis debemos realizarlo con otras entidades tales como fibromas, lipomas, sarcomas, tumores de glándulas salivares.12 Para ello se deben tomar biopsias de las lesiones que nos llevarán al diagnóstico mediante la realización de un análisis histológico.

El diagnóstico histológico de la amiloidosis se basa principalmente en sus características tintoriales. La tinción más utilizada es la de rojo Congo, aunque existen otras técnicas histoquímicas, menos utilizadas, que permiten diferenciar el amiloide de otras sustancias como son el violeta cristal o violeta de metilo y produce una fluorescencia secundaria con luz ultravioleta cuando se tiñe con las tioflavinas T o S. El diagnóstico también puede confirmarse con el microscopio electrónico.

La amiloidosis se debe sospechar ante un paciente con una enfermedad sistémica de base de larga evolución, sobre todo en las relacionadas con discrasias plasmocelulares, entre las que destaca por su mayor frecuencia el mieloma múltiple.

La amiloidosis lingual se asocia frecuentemente a cuadros de amiloidosis primaria en el contexto de discrasias plasmocelulares, con la hiperproducción de cadenas ligeras de inmunoglobulinas $\mathrm{AL}$ y afectación sistémica. Más del $88 \%$ de los pacientes con amiloidosis sistémica primaria, y el total de los pacientes con mieloma múltiple y amiloidosis sistémica presentan la existencia de cadenas ligeras monoclonales o también denominadas proteína de Bence Jones en suero $u$ orina. ${ }^{8}$ Debemos entonces, una vez realizado el diagnóstico histológico, emprender un diagnóstico de extensión, mediante la realización de analíticas, electrocardiograma, ecocardiografía, radiografía de tórax, etc., valorando la posible afectación de otros sistemas del organismo.

\section{Conclusiones}

Entre las patologías orales que cursan con nódulos a nivel de las mucosas, la amiloidosis se trata de una entidad rara, pero que debemos tener en cuenta en el diagnóstico diferencial. Hay que sospecharla ante la aparición de lesiones nodulares en pacientes con enfermedades crónicas, y en alteraciones hematológicas que cursan con discrasias plasmocelulares. En caso de hallar lesiones amiloidóticas en la mucosa oral u otra localización específica, se debe realizar una batería de pruebas encaminadas a descubrir una enfermedad sistémica subyacente. Por otro lado, ante la sospecha de una posible amiloidosis sistémica, no debe pasarse por alto durante la exploración física, la búsqueda de posibles lesiones a nivel de la cavidad oral. may not fit inside the oral cavity due to its volume and may even impede ventilation. ${ }^{14}$ In these advanced cases, treatment must be surgical, consisting of partial glossectomy to alleviate the symptoms and diminish the aesthetic impact ..$^{15}$

Our patient did not present macroglossia, but the second disorder described in the oral cavity characteristic of this disease, although much rarer, consisting of nodular lesions of the tongue and lips. These lesions also are reported in submandibular glands. In a series published by Van der Waal et al in 2002,11 of 11 cases of amyloidosis of the oral cavity in a period of 31 years of follow-up, only 2 appeared in the form of amyloid nodules, while the remaining 9 manifested as macroglossia. These alterations consist of nodular lesions of diverse sizes, indurated on palpation, and frequently adopting a yellowish white color. ${ }^{16}$ They are distributed throughout the lingual surface, being found mainly towards the back. They also can be observed in other areas of the oral mucosa like the palate, gums, floor of the mouth and lips, as in the case of the patient described.

The differential diagnosis of amyloidosis nodules should be made with disorders like fibromas, lipomas, sarcomas, and salivary gland tumors. ${ }^{12}$ Biopsies should be made of the lesions to diagnose them by histological analysis.

The histological diagnosis of amyloidosis is based mainly on its staining characteristics. The stain most often used is Congo red, although other less frequently used, histochemical techniques exist that allow amyloid to be differentiated from other substances, such as crystal violet or methyl violet, which produces secondary fluorescence with ultraviolet light when dyed with thioflavines T or S. The diagnosis can be confirmed by electron microscopy.

Amyloidosis should be suspected in patients with underlying systemic disease of long duration, particularly those related to plasmocellular dyscrasias, among which multiple myeloma is notable due to its frequency.

Lingual amyloidosis frequently is associated with primary amyloidosis in the context of plasmocellular dyscrasias, with hyperproduction of light chains of AL immunoglobulins and systemic involvement. More than $88 \%$ of patients with primary systemic amyloidosis and the totality of patients with multiple myeloma and systemic amyloidosis present monoclonal light chains, also denominated Bence Jones protein, in serum or urine. ${ }^{8}$ Therefore, once the histological diagnosis is made, we must diagnose the extension by blood tests, electrocardiography, cardiac ultrasonography, chest radiograph, and others and assess the possible involvement of other body systems.

\section{Conclusions}

Among oral pathologies that course with mucosal nodules, amyloidosis is a rare condition, but it must be considered in the differential diagnosis. It must be suspected when nodular lesions occur in patients with chronic disease and in 


\section{Bibliografía}

1. Breathnach SM. Amyloid and amyloidosis. J Am Acad Dermatol 1988;18:1-16.

2. Touart DM, Sau P. Cutaneous deposition diseases. Part 1. J Am Acad Dermatol 1998;39:149-71.

3. Kyle RA, Linos A, Beard CM, Linke RP, Gertz MA, O’Fallon WM, et al. Incidence and natural history of primary systemic amiloidosis in Olmsted County, Minnesota, 1950 through 1989. Blood 1992;79:1817-22.

4. Kyle RA, Gertz MA. Systemic amyloidosis. Crit Rev Oncol Hematol 1990;10:4987.

5. Röcken C, Schwotzer EB, Linke RP, Saeger W. The classification of amyloid deposits in clinicopathological practice. Histopathology 1996;29:325-35.

6. Husby G. Nomenclature and classification of amyloid and amiloidoses. J Intern Med 1992;232:511-2.

7. Westermark P, Araki S, Benson MD, Buxbaum JN, Cohen AS, Frangione B, lkeda S, Masters CL, Merlini G, Saraiva MJ, Sipe JD. Nomenclature of amyloid fibril proteins. Report from the meeting of the International Nomenclature Committee on Amyloidosis, August 8-9, 1998. Part 1. Amyloid 1999;6:63-6.

8. Gertz MA, Kyle RA. Primary systemic amiloidosis. A diagnostic primer. Mayo Clin Proc 1989;64:1505-19.

9. Kyle RA, Gertz MA. Primary systemic amyloidosis: clinical and laboratory features in 474 cases. Semin Hematol 1995;32:45-59.

10. Mateo Arias J, Molina Martinez M, Borrego A, Mayorga F. Amiloidosis of the submaxillary gland. Med Oral 2003;8:66-70.

11. Van der Waal RI, van de Scheur MR, Huijgens PC, Starink TM, van der Waal I. Amyloidosis of the tongue as a paraneoplastic marker of plasma cell dyscrasia. Oral Surg Oral Med Oral Pathol Oral Radiol Endod 2002;94:444-7.

12. Fahrner KS, Black CC, Gosselin BJ. Localized Amyloidosis of the tongue: a review. Am J Otolaryngol 2004;25:186-9.

13. Stoor P, Suuronen R, Lindqvist C, Hietanen J, Laine P. Local primary (AL) amiloidosis in the palate. A case report. Int J Oral Maxilofac Surg 2004;33:402-3.

14. Rodriguez J, Gonzalez J, Raspall G. Primary amyloidosis with severe macroglosia. Med Oral 2000;5:36-41.

15. Mardinger O, Rotenberg L, Chaushu G, Taicher S. Surgical management of macroglossia due to primary amyloidosis. Int J Oral Maxillofac Surg 1999;28:129-31.

16. Guccion JG, Redman RS, Winne CE. Hemodialysis-associated amyloidosis presenting as lingual nodules. Oral Surg Oral Med Oral Pathol 1989;68:618-23. hematological disorders that course with plasmocellular dyscrasia. When amyloid lesions are found in the oral mucosa or other specific location, a battery of tests must be carried out to discover the underlying systemic disease. On the other hand, when a possible systemic amyloidosis is suspected, the search for possible lesions in the oral cavity should not be overlooked during the physical examination. 